\title{
Play It Again, Sam
}





\section{Play It Again, Sam Retakes on Remakes}

\section{Andrew Horton and Stuart Y. McDougal}

with an Afterword by Leo Braudy 
University of California Press

Berkeley and Los Angeles, California

University of California Press, Ltd.

London, England

(C) 1998 by

The Regents of the University of California

\section{Library of Congress Cataloging-in-Publication Data}

Play it again, Sam : retakes on remakes / edited by Andrew Horton and Stuart Y. McDougal ; with an afterword by Leo Braudy.

p. $\mathrm{cm}$.

Includes bibliographic references and index.

ISBN 0-520-20592-8 (cloth : alk. paper). - ISBN 0-520-20593-6 (pbk. : alk. paper)

1. Motion picture remakes. I. Horton, Andrew. II. McDougal, Stuart Y. PN1995.9.R $45_{5} \mathrm{P}_{5} \quad 1998$

$791.43^{\prime} 75$-dc21

$97^{-175}$

CIP

Printed in the United States of America

$\begin{array}{lllllllll}9 & 8 & 7 & 6 & 5 & 4 & 3 & 2 & 1\end{array}$

The paper used in this publication meets the minimum requirements of American National Standards for Information Sciences-Permanence of Paper for Printed Library Materials, ANSI Z39.48-1984. 